\title{
Factors Affecting the Failure of Patient Safety Target Indicators in The Regional Hospital of The Datu Beru Takengon Central Aceh
}

\author{
Ainal Mardiah ${ }^{1}$, Mappeaty Nyorong ${ }^{2}$, Jamaluddin ${ }^{2}$ \\ ainalmardiah72@gmail.com \\ ${ }^{1}$ Master student of the Faculty of Public Health, Helvetia Institute of Health, Indonesia \\ ${ }^{2}$ Lecturer at the Faculty of Public Health, Helvetia Institute of Health, Indonesia \\ Received: September 21, 2020 \\ Revised: September 28, 2020 \\ Accepted: September 30, 2020
}

\begin{abstract}
The application of patient safety management is very important in an effort to prevent or minimize the occurrence of adverse patient safety incidents. The purpose of this study was to identify the factors that influence the achievement of patient safety target indicators. The method is a quantitative observational study with a cross sectional study approach. The study population was a nurse who worked in the inpatient room with a sample of 60 people who were taken by purposive sampling. The statistical test used is Multiple Linear Regression Analysis. The results of the Multiple Linear Regression Test show that knowledge, communication systems, commitment and experience (regression coefficient values of $0.164,1.1192,0.528$ and 1.169 have a positive influence on the achievement of patient safety goal indicators and leadership, risk management systems and reporting systems have a significant influence. negative impact on the achievement of patient safety target indicators (regression coefficient values of $-0.064,-0.967$ and -0.281 ). The results of the $t$ test were obtained that the communication system is the dominant factor that has a significant effect on the achievement of the patient safety goal indicators. significant towards the achievement of patient safety target indicators.It is expected that input or consideration for the hospital in evaluating and improving hospital policies in increasing the achievement of patient safety target indicators is in accordance with existing targets.
\end{abstract}

Keywords: Patient Safety Target Indicators, Unattainable Factors

\section{Introduction}

According to a report by the World Health Organization (WHO) estimates show that in highincome countries, as many as one in 10 patients are harmed while receiving hospital care. Losses can be caused by a variety of adverse events, with nearly $50 \%$ of events considered preventable. A study on the frequency and prevention of adverse events in 26 hospitals in eight low and middleincome countries, showed an adverse event rate of around $8 \%$. with $83 \%$ preventable and meanwhile about $30 \%$ associated with patient mortality (WHO, 2019).

The occurrence of side effects, resulting from unsafe treatments, is likely to be one of the top 10 causes of death and disability worldwide. Recent evidence suggests that 134 million adverse events occur each year due to unsafe hospital care in low- and middle-income countries, resulting in 2.6 million deaths annually (WHO, 2019). Patient safety culture is an important indicator of quality in health care and has been linked to patient outcomes in the hospital (Sorra \& Dyer, 2010; Lyu et al., 2013; Li et al., 2019). 
A patient safety culture was developed in an effort to reduce the risk of harm in the hospital and improve patient safety. However, based on several research results, it was found that the implementation of safety in several hospitals in Indonesia was still low. Based on Yusuf's (2017) research on the application of patient safety in Class III Inpatient Rooms at the Regional General Hospital (RSUD) dr. Zainoel Abidin Banda Aceh showed that 31 nurses (50.8\%) had good patient safety practices. According to research Must. BDdkk, $68.3 \%$ of the target patient safety at Panti Waluyo Sawahan Hospital Malang is still lacking. Meanwhile, the implementation of patient safety at Bantul Hospital is in the good category of 55\% (Fitriana \& Pratiwi, 2018). Based on these data, it can be seen that there is still a lack of application of patient safety in hospitals.

The compliance of officers in implementing and implementing patient safety goals is expected to reduce the trend of incidents from patient safety goals. However, based on the results of Savitri's (2019) study, the number of incidents reported by the hospital's patient quality and safety team during 2017 was 138 incidents. Based on the documentation study, 136 incidents (98.6\%) were reported related to SKP (Employee Performance Target) 1 to SKP 6 and 2 incidents (1.4\%) related to facilities (Budi et al., 2019). And the results of research Kagan and Barnoy (2013) also reported that most nurses experience medical errors every day of every week and $6 \%$ never report their own mistakes (Kagan \& Barnoy, 2013).

Regional General Hospital (RSUD) Datu Beru Takengon Aceh Tengah is one of the government hospitals which has also implemented a patient safety program since 2008. In PMK No. 129 of 2008 concerning Minimum Hospital Service Standards that the occurrence of standard patient safety incidents is $0 \%$ or $100 \%$ does not occur in the hospital. However, patient safety incidents at Datu Beru Takengon Regional Hospital in Aceh are still happening. This is based on the report of the Patient Safety Committee of the Datu Beru Takengon Regional Hospital in Central Aceh, namely in January-December 2019 there were 105 incidents consisting of 30 KTD (28.5\%), 54 KNC (51.4\%), and KTC and others. 21 incidents (20\%). Most of the reported patient safety incidents occurred in the inpatient ward. In addition, based on reports and data analysis of the Healthcare Association Infection (HAIs) Datu Beru Takengon Regional Hospital in Central Aceh, the incidence of phlebitis infection in 2019 is still high at $10.2 \%$. Meanwhile, the minimum hospital service standard for nasocomial infection indicators remains $\leq 1.5 \%$. This shows that the application of patient safety targets is still low in the Datu Beru Takengon Regional Hospital in Central Aceh. This is also reinforced from the data on the quality improvement and patient safety program report at Datu Beru Takengon Central Aceh Hospital in 2019 which shows: Compliance of officers in identifying patients correctly $79.8 \%$, Compliance with the implementation of site marking procedures for patients who will undergo surgery $90,9 \%$ and compliance with hand washing is still low, namely still $69,1 \%$.

Based on the application of the above problems, there are still finding indicators of patient safety targets that have not been achieved, and are related to the incidence of patient safety incidents in the inpatient room. The purpose of this study was to identify the factors that influence the achievement of patient safety target indicators.

\section{Methods}

This research is a quantitative observational study using a cross sectional study approach. The population in this study were all nurses who worked in the inpatient room of Datu Beru Takengon

Copyright $@$ 2020, Journal of Asian Multicultural Research for Educational Study, Under the license CC BY-SA 4.0 
Regional Hospital in Central Aceh. The sample taken in this study were 60 people with the sampling technique using purposive sampling.

The research tools or instruments used in this study were questionnaires and checklists. The data analysis used is multiple linear regression analysis to measure the factors that influence the failure to achieve patient safety target indicators at Datu Beru Takengon Hospital, Central Aceh. Multiple linear regression analysis is used to see the effect of the independent variable on the dependent variable and to predict the value of the dependent variable using the independent variable.

\section{Results and Discussion}

\section{Description of Nurse Characteristics}

The study was conducted on 60 respondents, namely nurses who carry out Datu Beru Takengon Regional Hospital with the following characteristics:

Table 1 Characteristic Distributions of Research Respondents Factors Affecting Unachieved Target Indicators for Patient Safety at Datu Beru Takengon Hospital, Central Aceh

\begin{tabular}{lcc}
\hline \multicolumn{1}{c}{ Nurse Characteristics } & N & Percentage \\
\hline Sex & 13 & \\
\hline Male & 47 & $21,7 \%$ \\
\hline Female & & $78,3 \%$ \\
\hline Age & 8 & \\
\hline a. 17-25 Years & 39 & $13,3 \%$ \\
\hline b. 26-35 Years & 12 & $65,0 \%$ \\
\hline c. $36-45$ Years & 1 & $20,0 \%$ \\
\hline d. 46-55 Years & & $1,7 \%$ \\
\hline Education & 16 & \\
\hline a. DIII & 1 & $26,7 \%$ \\
\hline b. DIV & 15 & $1,7 \%$ \\
\hline c. S1 (Undergraduate) & 27 & $25,0 \%$ \\
\hline d. S1 (Undergraduate)+Ners & 1 & $45,0 \%$ \\
\hline e. S2 (Master) & 60 & $1,7 \%$ \\
\hline Total & & 100 \\
\hline
\end{tabular}

Based on table 1, it is illustrated that the characteristics of the nurses who became respondents in this study were the majority with female gender as much as $78.3 \%$, as many as $65 \%$ with an age limit of 26-35 years and 45\% with the latest education S1 + Ners.

\section{Classic assumption test}

The classical assumption tests carried out in this study were the normality test, multicollinearity test and heterocedacity test.

a. Normality test

Table 2. Normality Test Results

\begin{tabular}{llll}
\hline Variable & Sig (2-tailed) & p-value & Description \\
\hline
\end{tabular}




\begin{tabular}{|c|c|c|c|}
\hline $\begin{array}{l}\text { Undstadardized } \\
\text { residual }\end{array}$ & 0,200 & 0,05 & Normal \\
\hline
\end{tabular}

Based on the results of normality testing by looking at the Kolmogorov-Smirnov value of the unstandardized residual data is 0.200 , it can be seen that the $p$-value for the data is greater than $\alpha$ $=5 \%(\mathrm{p}>0.05)$, so it can be stated that the overall data obtained has a distribution normal.

b. Multicollinearity test

Table 3. Multicollinearity Test Results

\begin{tabular}{lcccl}
\hline \multicolumn{1}{c}{ Variable } & Tolerance & VIF & A & \multicolumn{1}{c}{ Description } \\
\hline Leadership & 0.745 & 1.342 & 10 & $\begin{array}{l}\text { Multicollinearity } \\
\text { does not occur }\end{array}$ \\
\hline Knowledge & 0.555 & 1.801 & 10 & $\begin{array}{l}\text { Multicollinearity } \\
\text { does not occur }\end{array}$ \\
\hline $\begin{array}{l}\text { Communication } \\
\text { system }\end{array}$ & 0.506 & 1.975 & 10 & $\begin{array}{l}\text { Multicollinearity } \\
\text { does not occur }\end{array}$ \\
\hline $\begin{array}{l}\text { Risk management } \\
\text { system }\end{array}$ & 0.467 & 2.143 & 10 & $\begin{array}{l}\text { Multicollinearity } \\
\text { does not occur }\end{array}$ \\
\hline Commitment & 0.397 & 2.516 & 10 & $\begin{array}{l}\text { Multicollinearity } \\
\text { does not occur }\end{array}$ \\
\hline Reporting System & 0.563 & 1.776 & 10 & $\begin{array}{l}\text { Multicollinearity } \\
\text { does not occur }\end{array}$ \\
\hline Experience & 0.574 & 1.743 & 10 & $\begin{array}{l}\text { Multicollinearity } \\
\text { does not occur }\end{array}$ \\
\hline
\end{tabular}

In table 2 , it can be seen that VIF $<10$ and the tolerance value $>0.1$, so there is no multicollinearity c. Heteroscedacity test

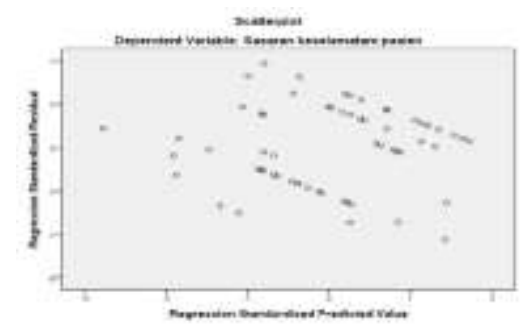

Figure 1. Scaterplot of Heteroscedasticity Test Results

The points in the image above do not form a regular pattern, but are scattered both above the number 0 and below the number 0 on the $\mathrm{Y}$ axis. Based on the diagram above, it can be concluded that there is no heteroscedasticity in the regression model so that research can be continued.

\section{Model Accuracy Testing}


a. Simultaneous Significance Test (Test F)

Table 4. F Test Results

\begin{tabular}{|c|c|c|c|c|c|c|}
\hline & & $\begin{array}{c}\text { Sum of } \\
\text { Squares }\end{array}$ & $\mathrm{df}$ & $\begin{array}{c}\text { Mean } \\
\text { Square }\end{array}$ & $\mathrm{F}$ & Sig. \\
\hline \multirow[t]{3}{*}{1} & Regression & 2587.329 & 7 & \multirow{3}{*}{$\begin{array}{r}369.618 \\
86.008\end{array}$} & \multirow[t]{3}{*}{4.298} & \multirow[t]{3}{*}{$.001^{\mathrm{b}}$} \\
\hline & Residual & 4472.404 & 52 & & & \\
\hline & Total & 7059.733 & 59 & & & \\
\hline
\end{tabular}

Based on the table above, it can be seen that the Fcount value (4.298) is greater than the F table (2.19) with a significance of 0.001 ( $\mathrm{p}<0.05$ ). Thus it can be said that knowledge, leadership, communication systems, risk management systems, commitment, reporting systems and experience together have an effect on the achievement of patient safety goal indicators.

b. Coefficient of Determination (R2 Test)

Table 5. Coefficient of Determination

Model Summaryb

\begin{tabular}{|l|l|r|r|r|}
\hline Model & $\mathrm{R}$ & $\begin{array}{c}\mathrm{R} \\
\text { Square }\end{array}$ & $\begin{array}{c}\text { Adjusted R } \\
\text { Square }\end{array}$ & \multicolumn{2}{|c|}{$\begin{array}{c}\text { Std. Error of the } \\
\text { Estimate }\end{array}$} \\
\hline 1 & $.605^{\mathrm{a}}$ & .366 & .281 & \multicolumn{2}{c|}{9.274} \\
\hline
\end{tabular}

Table 5 shows that the coefficient of determination shown from the adjusted $\mathrm{R}$ square value is 0281. This means that only $28.1 \%$ of the achievement of patient safety target indicators can be explained by independent factors, namely knowledge, leadership, communication systems, risk management systems, commitment., reporting systems and experiences. While the remaining $71.9 \%$ is explained by other variables that are not included in the regression model in this study.

\section{Hypothesis test}

The data analysis method used in this study is multiple regression models. Multiple linear regression analysis is used to determine the effect between two or more independent variables and the dependent variable.

Table 6. Results of Regression Test and T-Test

\begin{tabular}{lcccc}
\hline \multicolumn{1}{c}{ Variable } & Kooefisien & $\mathrm{T}_{\text {count }}$ & Sig. & Conclusion \\
\hline (Constant) & 10.811 & & & \\
\hline Knowledge (X1) & 0.164 & 1.214 & 0.230 & $\begin{array}{c}\text { No effect, not } \\
\text { significant }\end{array}$ \\
\hline Leadership (X2) & -0.064 & $\begin{array}{c}- \\
0.171\end{array}$ & 0.865 & $\begin{array}{c}\text { No effect, not } \\
\text { significant }\end{array}$ \\
\hline $\begin{array}{l}\text { Communication } \\
\text { system (X3) }\end{array}$ & 1.196 & 3.490 & 0.001 & $\begin{array}{c}\text { Influential, } \\
\text { Significant }\end{array}$ \\
\hline
\end{tabular}




\begin{tabular}{|c|c|c|c|c|}
\hline $\begin{array}{l}\text { Risk management } \\
\text { system (X4) }\end{array}$ & -0.967 & $\begin{array}{c}- \\
1.324\end{array}$ & 0.191 & $\begin{array}{c}\text { No effect, no } \\
\text { significant }\end{array}$ \\
\hline Commitment (X5) & 0.528 & 1.092 & 0.280 & $\begin{array}{l}\text { No effect, not } \\
\text { significant }\end{array}$ \\
\hline $\begin{array}{l}\text { Reporting System } \\
\text { (X6) }\end{array}$ & -0.281 & $\begin{array}{c}- \\
0.810\end{array}$ & 0.422 & $\begin{array}{l}\text { No effect, not } \\
\text { significant }\end{array}$ \\
\hline Experience $(\mathrm{X} 7)$ & 1.169 & 0.785 & 0.436 & $\begin{array}{c}\text { No effect, no } \\
\text { significant }\end{array}$ \\
\hline \multicolumn{5}{|c|}{$\begin{array}{l}\mathrm{F}_{\text {count }}=4,298 \\
\text { Adjusted } \mathrm{R} \text { square }=0281\end{array}$} \\
\hline
\end{tabular}

\section{a. Multiple Linear Regression Test}

The regression equation is as follows:

\section{SKP =10,811+0,164X1-0,064X2+1,196X3-0,967X4+0,528X6-0,281X6+1,169X7}

The interpretation of each coefficient of the variable is as follows:

1) A constant value of 10.811 indicates that if the independent variables are Knowledge, Leadership, Communication Systems, Risk Management Systems, Commitment, Reporting Systems and Experience, if the value is 0 then the achievement of patient safety goal indicators is 10.811 .

2) The regression coefficient on the Knowledge variable is 0.164 (positive sign), indicating that each increase in knowledge of $1 \%$ will increase the achievement of the patient's Safety Goal Indicator by 0.164 assuming the other independent variables are constant.

3) The regression coefficient on the Leadership variable of- 0.064 (negative sign) indicates that every 1 unit increase in leadership in patient safety management will reduce the achievement of the Patient Safety Goal Indicator by 0.064 , assuming the other independent variables are constant.

4) The regression coefficient on the communication system variable is 1.196 (positive sign), indicating that each increase in the communication system in the application of patient safety management by 1 unit will increase the achievement of the Patient Safety Goal Indicator by 1.196 assuming the other independent variables remain.

5) The regression coefficient on the Risk Management System variable is -0.967 (negative sign) indicates that an increase in the risk management system in patient safety management by 1 unit will reduce the achievement of the Patient Safety Goal Indicator by 0.967, assuming the other independent variables remain.

6) The regression coefficient on the Commitment variable is 0.528 (positive sign), indicating that each increase in the commitment of nurses in implementing patient safety management 1 unit will increase the achievement of the Patient Safety Goal Indicator by 0.528 assuming the other independent variables are constant.

7) The regression coefficient on the Reporting System variable is -0.281 (marked negative), indicating that any increase in the reporting system in the application of safety management for 
1 patient unit will reduce the achievement of Patient Safety Indicators by 0.281 assuming the other independent variables remain.

8) The regression coefficient on the Experience variable is 1.169 (marked negative), indicating that each increase in the experience of nurses in carrying out patient safety management 1 unit will increase the achievement of the Patient Safety Goal Indicator of 1.169 assuming the other independent variables remain

b. Individual Partial Significance Test (T Test)

The strength of the relationship that occurs between each independent variable on the dependent variable is as follows:

1) Knowledge

From the results of the estimation of the knowledge variable, it is obtained that the t value of 1.214 is smaller than the $t$ table value of 2.006647 and the significance value of 0.575 is greater than 0.05 , so that the testing hypothesis is Ha rejected. Therefore, it can be concluded from these results that partially knowledge has no effect and is not significant to the achievement of patient safety goal indicators.

2) Leadership

From the estimation results of the leadership variable, it is obtained that the $t$ count of -0.171 is smaller than the $t$ table value of 2.006647 and a significance value of 0.865 is greater than 0.05 , so the testing hypothesis is Ha rejected. Therefore, it can be concluded from these results that partially leadership has no and insignificant effect on the achievement of patient safety goal indicators.

3) Communication System

From the estimation results of the communication system variable, it is obtained that the $t$ value of 3,490 is greater than the $t$ table value of 2.006647 and the significance value of 0.001 is less than 0.05 , so that the testing hypothesis is Ha accepted. Therefore, it can be concluded from these results that partially the communication system has a significant and significant effect on the achievement of patient safety goal indicators.

4) Risk Management System

From the estimation results of the risk management system variable, it is obtained that the $t$ value of -1.324 is smaller than the $t$ table value of 2.006647 and the significance value of 0.191 is greater than 0.05 , so the testing hypothesis is Ha rejected. Therefore, it can be concluded from these results that partially the risk management system has no and insignificant effect on the achievement of patient safety goal indicators.

5) Commitment

Dari hasil estimasi variabel komitmen diperoleh nilai t hitung 1.092 lebih kecil dari nilai $t$ tabel 2,006647 serta nilai signifikansi sebesar 0.280 lebih besar dari 0,793 , sehingga hipotesis pengujian adalah Ha ditolak. Oleh karena itu, dapat disimpulkan dari hasil tersebut bahwa secara parsial komitmen tidak berpengaruh dan tidak signifikan terhadap pencapaian indikator sasaran keselamatan pasien.

6) Sistem Pelaporan 
From the estimation results of the reporting system variable, it is obtained that the $t$ value of 0.810 is smaller than the $t$ table value of 2.006647 and the significance value of 0.422 is greater than 0.05 , so that the testing hypothesis is Ha rejected. Therefore, it can be concluded from these results that partially the reporting system has no and insignificant effect on the achievement of patient safety goal indicators.

\section{7) Experience}

From the results of the estimation of the knowledge variable, it is obtained that the $t$ value of 0.785 is smaller than the $t$ table value of 2.006647 and the significance value of 0.436 is greater than 0.05 , so that the testing hypothesis is Ha rejected. Therefore, it can be concluded from these results that partially experience has no and insignificant effect on the achievement of patient safety goal indicators.

Based on the results of tests that have been conducted by researchers, the results of the t test show that knowledge has no effect on the achievement of patient safety goal indicators. The results of this study support the hypothesis in the direction of the sign which states that knowledge has a positive and insignificant effect on the achievement of patient safety goals. The direction of the positive sign shows that if knowledge has increased, the achievement of the patient safety target indicators will also increase, but the increase is not significant.

Based on the results of the regression test, knowledge has a positive effect on the patient safety target indicators. This means that the higher the knowledge, the higher the achievement of the patient safety target indicators. This result is in accordance with the theory explained by Notoadmodjo (2012) that behavior based on knowledge will be better than bad behavior based on knowledge because it is based on awareness, interest, and positive consideration and attitude.

The results of the study support the hypothesis of this study that knowledge has an effect on the achievement of patient safety target indicators, but not significantly. This can be seen from the results of the research that on certain aspects of knowledge about patient safety goals that are true, it is found that nurses carry out well according to their knowledge. However, certain knowledge also, such as communication methods and increased drug control, need to be watched out for, which is found that the knowledge of nurses is high, but in its application it is not significant. Even though the knowledge of a nurse is high, in certain situations and conditions nurses often forget or do not implement patient safety properly such as stress conditions, fatigue and internal conflicts and facilities that do not support the application of patient safety. These conditions were neither studied nor controlled in this study.

Nurses' knowledge that is good enough is expected to increase awareness of care in realizing hospital patient safety in order to avoid an increase in patient safety incidents. However, based on the item of knowledge, it was found that nurses' knowledge was still low about the standards for improving the safety of drugs that needed to be monitored and was directly proportional to the application of these standards. This can be seen from the observation results of the implementation of patient safety target indicators, it is found that the implementation of standards for improving the safety of drugs that need to be watched is still in the poor category And the test results in each question item found $98.1 \%$ of nurses answered incorrectly about the principle of drug administration and $61.7 \%$ of nurses also answered wrong things that need to be watched out for increasing safety of drugs. This shows that there is still low knowledge of nurses on standard III, namely increasing the safety of drugs that need to be watched out for. 
Based on the results of the tests conducted by researchers, the results of the test show that leadership has no effect on the achievement of patient safety goal indicators. The results of this study support the hypothesis in the direction of the sign which states that leadership has a negative and insignificant effect on the achievement of patient safety goals. The direction of the negative sign shows that if leadership has increased, then the achievement of the patient safety goal indicators has decreased, but the decrease is not significant.

Based on the results of tests that have been carried out by researchers, the results of the test show that the communication system has an effect on the achievement of patient safety target indicators. The results of this study also support the sign direction hypothesis which states that the communication system has a positive and significant effect on the achievement of patient safety goals. The direction of the positive sign shows that if the communication system is getting better, the achievement of the patient safety target indicators is also getting better and the increase is also significant.

This result is supported by research by Rivai et al (2016) using the chi-square value obtained by $\mathrm{p}$ $=0.004$, which means that there is a significant relationship between communication and implementation of patient safety by the nurse in the inpatient room of Ajjappannge Soppen Hospital with the variable relationship being in the medium category. . The research of Ismainar et al (2012) also strengthens the results of this study through qualitative research conducted with the result that the results of the Indept Interview conducted with 13 informants have the same perception. The involvement of members in solving KTD problems is only individual in accordance with the scene. There is a tendency that communication between internal teams is rarely done. Even though communication is the most important element that cannot be separated in a teamwork. Communication is a process, an activity.

Based on the test results that have been conducted by researchers, the test results show that the risk management system has no effect on the achievement of patient safety goal indicators. The results of this study support the sign direction hypothesis which states that the risk management system has a negative and insignificant effect on the achievement of patient safety goals. The direction of the negative sign indicates that if the risk management system has increased, then the achievement of the patient safety target indicators has decreased, but the decrease is not significant.

The results of hypothesis testing found that the risk management system has a negative effect on the patient safety target indicator. This can be seen from the responses of the nurses who stated that they often and always carry out the risk management process based on the risk management SOP that has been established by the hospital. Based on the results of the answers, it was found that there were more answers than always. This shows the low commitment in implementing a risk management system. To increase nurse commitment, an organizational climate and leadership commitment are needed in encouraging nurses to always carry out patient safety risk management.

Based on the results of the tests conducted by researchers, the results of the test show that commitment does not affect the achievement of patient safety goal indicators. The results of this study support the hypothesis in the direction of the sign which states that commitment has a positive and insignificant effect on the achievement of patient safety goal indicators. The direction of the positive sign shows that if the commitment has increased, then the achievement of the patient safety target indicators will also increase, but the increase is not significant. The results of hypothesis testing show that commitment has a positive direction, namely the higher the 
commitment of nurses, the higher the achievement of the SKP indicator. According to Hendroyogi \& Harsono (2016), organizational commitment has an impact on performance.

Greenberg et al (1993) argued that work commitment reflects the level of identification and involvement of individuals in their work and their unwillingness to leave the job. This theory supports the findings that care response to commitment where $45.1 \%$ answered always and $43.2 \%$ answered frequently in the application of patient safety management. This shows that the data shows that it is better because the majority of nurses say they often and always.

The positive effect of this commitment is insignificant on indicator achievement. The researchers estimate, this is probably due to the fact that nurses' commitment is more likely to be limited to an obligation. Ideally, this work commitment is not only a commitment to obligations or continuity, but also a work commitment that has a psychological relationship. Where nurses persist in their work because they want it to be realized that they always work as they should in supporting patient safety performance. And in this study, nurses found a tendency to have a normative work commitment, namely on the basis of obligations.

In addition to the researchers' estimates, there might be things that reinforce influential commitments such as support and training that is attended by nurses. As stated by Feng et al (2011) adding training related to safety and real support for patient safety culture are two things that also show management's commitment to patient safety culture. And in research, intention or psychology, support and training are not researched or hypothesis testing is done in this study.

The good intention of a nurse and support from all parties in encouraging nurses to carry out safety management including patient safety training for all nurses will play an important role in efforts to improve the implementation of patient safety management in hospitals (Pineda, 2015; Hartono et al., 2020).

The findings of the researchers showed that the reporting system did not significantly influence patient safety goals. Although the data findings on nurses' responses regarding the reporting system state that they often and always apply a patient safety reporting system, this does not guarantee that nurses actively report patient safety incidents. It is proven that many will sometimes report if they find a patient safety incident. Nurses' activeness in reporting patient safety incidents is influenced by the knowledge, leadership and work commitment of the nurses themselves.

The results showed that nurses answered more often than always. This shows that there is still no commitment by nurses in implementing the patient safety reporting system. This is reinforced by the finding that it has not reached 50\% of nurses who answered that they often report every patient safety incident correctly. This is also inseparable from the leadership role and organizational climate of the hospital and the nurse's own knowledge.

Based on the results of tests that have been conducted by researchers, the results of the $t$ test show that experience has no effect on the achievement of patient safety goal indicators. The results of this study support the hypothesis in the direction of the sign which states that experience has a positive and insignificant effect on the achievement of patient safety goals. The direction of the positive sign shows that the better the nurse's experience, the more the patient safety goal indicators will be, but the increase is not significant.

The results of hypothesis testing in this study indicate that experience has a positive influence on the patient safety achievement indicators. This means that the better the experience of nurses, the better the achievement of the SKP indicators. 
Although the hypothesis testing shows that there is no significant effect between experience and the achievement of patient safety goal indicators, it can be concluded from the regression coefficient that each increase will increase the achievement of patient safety goal indicators. The findings prove that nurses who have a working period of $\geq 5$ years, have attended training and have good enough knowledge have a tendency to implement patient safety target indicators in a good category. And vice versa nurses who have worked $<5$ years, have not received training and knowledge is less likely to apply patient safety targets in the sufficient category.

The insignificant effect of experience with the achievement of patient safety goal indicators may be due to other possible factors including working hours and stress. Factors Excessive working hours forced in certain rooms and stress can affect the performance of nurses and decreased alertness and will indirectly result in the application of patient safety goals. Even though the nurse is experienced and has received patient safety management training, excessive working hours and stress both in the work environment and internal conflicts of nurses also have an impact on the nurse's commitment to carrying out patient safety. This can be seen from the results of the study that found only 3 nurses who said they were always willing to maintain their emotions in order to communicate effectively in serving patients and teamwork.

The results of data testing found that the achievement of patient safety target indicators carried out by nurses who administered the Datu Beru Takengon Regional Hospital in Central Aceh was considered to be quite good. This can be seen from the results of observations or observations obtained by the achievement of patient safety target indicators by $80.4 \%$. And after testing each independent variable on the dependent variable, then continued with testing the effect of the independent variable simultaneously with the independent variable using multiple linear regression analysis. The results of multiple linear regression analysis using the $\mathrm{f}$ test. The results of hypothesis testing with the f test obtained F count $>\mathrm{F}$ table $(4.298>2.19)$ with a p-value of 0.001 $<0.05$, so that $\mathrm{Ha}$ is accepted, which means there is a simultaneous influence (jointly) between knowledge, leadership, systems communication, risk management system, commitment, reporting system and experience towards achieving patient safety goal indicators.

When viewed from the results of multiple linear regression analysis, it shows that the factors of knowledge, communication systems, commitment and experience have a positive relationship in increasing the achievement of patient safety indicators. Based on this, increasing knowledge of nurses, improving communication systems and increasing the commitment and experience of nurses in implementing patient safety will increase nurse compliance with the achievement of the hospital SKP indicator.

Based on the value of the regression coefficient, the communication system and the experience of nurses have a bigger impact in increasing the target achievement rate of the SKP indicator. In this case, the hospital needs to develop a policy to improve the experience of nurses in the form of increasing knowledge and understanding of nurses through continuous safety training so that nurses understand better patient safety, especially the concept of increasing drug safety which needs to be watched out for and prevention of the risk of falling patients.

The communication system is the dominant factor which significantly influences the achievement of the SKP indicators for the Datu Beru Takengon Regional Hospital in Central Aceh. This shows that the communication system has a t-count value greater than the t-table value with a significance value of $\mathrm{P}<0.05 \mathrm{U}$. An effective communication system has an influence on the implementation of patient safety. This is reinforced by only $47.4 \%$ of nurses who always use the SBAR

Copyright (C) 2020, Journal of Asian Multicultural Research for Educational Study, Under the license CC BY-SA 4.0 
communication system as an effective communication. And this has an effect on the achievement of SKP 2, an increase in Effective Communication, which was found to be $66.7 \%$. Poor communication systems will have an impact on health service problems received by patients. For this reason, RSUD Datu Beru Takengon Aceh Tengah needs to develop and implement policies that must be made to meet patient safety goals, especially increasing effective communication including policies and or procedures to direct the implementation of verification of the accuracy of oral or telephone communications consistently (write back, read back, format repeat back, and SBAR) and use of confirmation sheets for TBK (Write, Read, Confirm).

\section{Conclusion}

The communication system is a dominant factor that significantly influences the achievement of patient safety goal indicators. And the coefficient of determination shown from the adjusted $\mathrm{R}$ square value is 0281 , meaning that only $28.1 \%$ of the achievement of patient safety target indicators can be explained by independent factors, namely knowledge, leadership, communication systems, risk management systems, commitment, reporting systems and experience. While the remaining $71.9 \%$ is explained by other variables not included in the regression model. It is hoped that it can become input or consideration in evaluating and improving hospital policies in increasing the achievement of patient safety target indicators according to the target. And further research is needed to look at other factors that affect the achievement of patient safety indicators which are not examined in this study and need to further refine by developing research designs on variables that have a positive relationship but do not have a significant effect.

\section{References}

Budi, S. C., Sunartini, S., Lazuardi, L., \& Tetra, F. S. (2019). Tren Insiden Berdasarkan Sasaran Keselamatan Pasien. Jurnal Manajemen Informasi Kesehatan Indonesia (JMIKI), 7(2), 146.

Feng, X. Q., Acord, L., Cheng, Y. J., Zeng, J. H., \& Song, J. P. (2011). The relationship between management safety commitment and patient safety culture. International nursing review, 58(2), 249-254.

Fitriana, Y., \& Pratiwi, K. (2018). Pelaksanaan Patient Safety di Rumah Sakit Umum Daerah dan Rumah Sakit Umum Swasta Bantul Berdasarkan Ketentuan Undang-Undang Nomor 44 Tahun 2009 Tentang Rumah Sakit. Jurnal Kebidanan, 7(1), 28-39.

Greenberg, J., Baron, R. A., \& Grover, R. A. (1993). Behavior in organizations: Understanding and managing the human side of work. Ugeb.

Hartono, B., Hidayati, A., \& Kurniati, T. (2020). The Effect Of Heads'leadership And Nurses'job Motivation On Nursing Performance In The Hospital Inpatient Room. Jurnal Administrasi Kesehatan Indonesia, 8(2).

Hendroyogi, S., \& Harsono, M. (2016). Keterkaitan Antara Persepsi Pentingnya Akreditasi Rumah Sakit Dengan Partisipasi, Komitmen, Kepuasan Kerja, Dan Kinerja Karyawan. Jurnal Manajemen Dayasaing, 18(2), 122-137.

Ismainar, H., Dahesihdewi, A., \& Dwiprahasto, I. (2012). Efektivitas Kepemimpinan dan Komunikasi Tim Keselamatan Pasien di RSI Ibnu Sina Pekanbaru Riau. Jurnal Kesehatan Komunitas, 2(1), 2-8. 
Kagan, I., \& Barnoy, S. (2013). Organizational safety culture and medical error reporting by Israeli nurses. Journal of Nursing Scholarship, 45(3), 273-280.

Li, Y., Cen, X., Cai, X., \& Temkin-Greener, H. (2019). Perceived Patient safety culture in nursing homes associated with "Nursing Home Compare" performance indicators. Medical care, 57(8), 641-647.

Lyu, H., Wick, E. C., Housman, M., Freischlag, J. A., \& Makary, M. A. (2013). Patient satisfaction as a possible indicator of quality surgical care. JAMA surgery, 148(4), 362-367.

Notoadmodjo, S. (2012). Metode Penelitian Kesehtaan, Edisi Revisi, Jakarta: Rineka Cipta.

Pineda, R. O. (2015). Improving patient outcomes and nurse satisfaction through nurse-to-nurse communication. Widener University.

Rivai, F., Sidin, A. I., \& Kartika, I. (2016). Faktor yang berhubungan dengan implementasi keselamatan pasien di RSUD Ajjappannge Soppeng Tahun 2015. Jurnal Kebijakan Kesehatan Indonesia: JKKI, 5(4), 152-157.

Savitri. (2019). Trend Insiden Berdasarkan Sasaran Keselamatan Pasien Karanganyar. Jurnal Manajemen Informasi Kesehatan, 7(2).

Sorra, J. S., \& Dyer, N. (2010). Multilevel psychometric properties of the AHRQ hospital survey on patient safety culture. BMC health services research, 10(1), 199.

WHO. (2019). Patient Safety Fact File. Patient Safety and Risk Management Service Delivery and Safety.

Yusuf, M. (2017). Penerapan Patient Safety Di Ruang Rawat Inap Rumah Sakit Umum Daerah Dr. Zainoel Abidin Patient Safety Implementation In Ward Of Dr. Zainoel Abidin General Hospital. Jurnal Ilmu Keperawatan, 5(1), 1-6. 